\title{
Peristethium phaneroneurum (Loranthaceae): a new combination expands the distribution of the genus from Honduras to Brazil
}

\author{
Claudenir Simões Caires ${ }^{1,2}$ \& Cecília Oliveira de Azevedo ${ }^{1}$
}

\begin{abstract}
A new combination, Peristethium phaneroneurum, is proposed, based on Struthanthus phaneroneurus, described from Honduras in 1940 by Paul C. Standley. This new combination extending the geographical distribution of the genus from Honduras to the ecotone Amazon-Cerrado region of Brazil.
\end{abstract}

Key words: Mesoamerica, mistletoes, Struthanthus

The genus Peristethium Tiegh. has been largely overlooked until its re-establishment (Kuijt 2012). As currently circumscribed by Kuijt (2012) Peristethium comprise 15 species and is mainly characterized by chaffy scale leaves at the base of the inflorescences. Recently, Struthanthus reticulatus Rizzini was transferred to Peristethium (Caires et al. 2014) extending the geographical distribution of the genus to the central region of Brazil.

According to Kuijt (2012) Peristethium differs from Struthanthus Mart. based on the combination of two key features: presence of chaffy scale leaves at the determinate inflorescences and tiny anthers. Whereas "the development of several to many pairs of conspicuous chaffy scale leaves at the base and along the fertile axis tend to be caducous, but basal scale leaves often persist" (Kuijt 2012: 543), is not observed in any species of Struthanthus, while the other features are rare in this genus.

Struthanthus phaneroneurus Standl. has conspicuous chaffy scale leaves, observed in all type materials (Fig. 1c, d), indicating that it should be transferred to Peristethium.

The protologue and type material of this name, and other specimens were examined through virtual herbaria (A, B-W, F, K, MICH, MO, NY, $\mathrm{P}, \mathrm{S}, \mathrm{UC}$ and US, acronyms according to Thiers (continuously updated).
Peristethium phaneroneurum (Standl.) Caires, comb. nov.; Struthanthus phaneroneurus Standl., Publ. Field Mus. Nat. Hist., Bot. Ser. 9(4): 285. 1940. Struthanthus phaneroneurus Standl. \& Lundell, Contr. Univ. Michigan Herb. 8: 25. 1942, nom. superfl. - Type: HONDURAS. DEPT. YORO: Olanchito, Aguan river valley, parasitic on tree in semi-arid woodland near Coyoles, fl., 26.VII.1938, T.G. Yuncker, J.M. Koepper \& K.A. Wagner 8662 (holotype: F!; isotypes: K!, MICH!, MO!, NY 285247!, NY 285248!, S!, US!). Fig. 1a-d. Hemiparasite, erect, pendent to lianescent, glabrous, possible dioicious. Epicortical roots present in older internodes, producing secondary haustoria. Young stems ellipsoids, greenish; adult stems cylindrical, grayish, covered with rounded lenticels (Fig. 1d), brownish; internodes $1.5-3(-5.5) \times(0.2-) 0.3-0.5 \mathrm{~cm}$. Leaves petiolate, decussate rare alternate, in sicco coriaceous and shiny, concolorous, elliptic, elliptic-obovate to obovate, $(1.5-) 2.5-3.5(-5) \times 1.5-2.5(-3) \mathrm{cm}$, apex round or obtuse to emarginate mucronate, rare acute or truncated, base cuneate to decurrent, margin entire, hyaline; petiole (3-)4-5 $\mathrm{mm}$ long, canaliculated at adaxial region; festoonate brochidodromous venation, visible on both sides, median vein prominent on both sides, secondary, tertiary and quaternary veins evident, these are also prominent, especially on the adaxial surface. Inflorescence spike-shaped, $0.8-1 \mathrm{~cm}$ long, axillary or in leafless node (Fig. 1d), 1-3 per leaf axil, formed

\footnotetext{
'Universidade Estadual do Sudoeste da Bahia, Depto. Ciências Naturais, Estr. do Bem Querer, km 4, 45031-900, Vitória da Conquista, BA, Brazil.

${ }^{2}$ Author for correspondence: cscaires@hotmail.com
} 


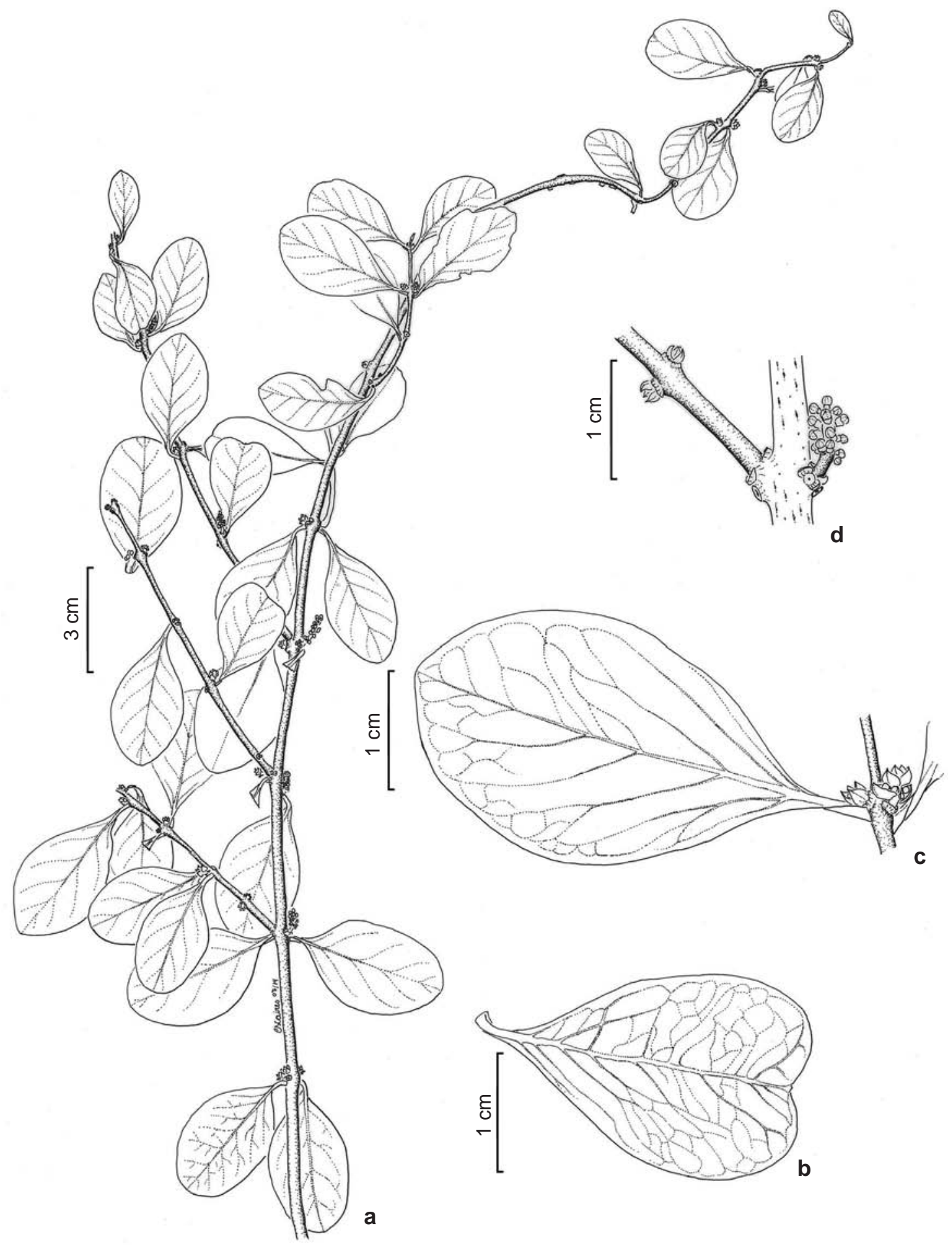

Figure 1 -Peristethium phaneroneurum (Standl.) Caires - a. habit; b. leaf morphological variation, with emarginate and mucronate apex; c. detail of nodal region with other leaf variation (obtuse apex) and young inflorescences protected for the chaffy scale leaves; d. detail of inflorescence and two young inflorescence inserted at leafless nodes. Drawn by C.S. Caires from Yuncker et al. $8662(\mathrm{NY})$. 
by a pair of triads sessile at its base, followed by a pair of dyads, ending with two pairs of monads and a terminal flower; young inflorescence and floral units protected by deciduous scale leaf (Fig. 1c), deltoid, apex acute. Flowers and fruits not observed.

Among the seven type specimens of Peristethium phaneroneurum, six were identified as Struthanthus interruptus (Kunth) G. Don, at different years. However, examining the type material of Loranthus interruptus Kunth (Humboldt \& Bonpland s.n., P 215980! and B-W 6983!) we noted that, although fragmented, specimens differ by the stem morphology (ellipsoids stems without grayish coverage nor presence of lenticels), by leaf morphology (alternate, elliptic, apex acute to obtuse and acute basis, with obscure venation), larger inflorescences (ca. $3.5 \mathrm{~cm}$ long) and total absence of traces of protective scale leaves at the inflorescences. The only characteristic which coincides with $P$. phaneroneurum are the sessile triads and probably the terminal flower.

When examining other materials identified as $S$. interruptus, we find specimens (Gentle 2660, A!, F!, K!, NY!, US!; Haenke s.n. MO 5117026!) that really are $S$. interruptus. Despite being in an advanced stage of fructification, these specimens showed no trace of the set of scale (Fig. 1c) seen in $P$. phaneroneurum.

Once we have confirmed that the specimen Yuncker et al.8662 was not S. interruptus, we examined the other 15 species of the genus Peristethium as proposed by Kuijt (2012), and the species proposed by Caires et al. (2014). Struthanthus interruptus was related to Peristethium only in Kuijt (2012: 544) that, when commenting on the bent style found in $P$. polystachyum (Ruiz \& Pav.) Kuijt and P. tortistylum (Kuijt) Kuijt, common to almost all species of Cladocolea Tiegh., also indicates its occurrence in $S$. interruptus. The leaves of P. nitidum (Kuijt) Kuijt and $P$. peruviense (Kuijt) Kuijt are similar to those of $P$. phaneroneurum, however the stems, petioles and inflorescences are distinct among these species (Fig. $1 b, c)$. Based on those analyses and in the conspicuous chaffy scale leaves, observed in all type materials, we conclude that Struthanthus phaneroneurus should be transferred to Peristethium.

With the new combination here proposed, the geographic distribution of Peristethium, so far with the northern limit of distribution in Costa Rica, is extended, occurring in Honduras, Panama, Venezuela, Colombia, Ecuador, Peru, Bolivia and Brazil, and comprising 17 species.
Lundell (1942) extends the range of this species to Mexico and expands its original description, based on E. Matuda 3856 (Tabasco, Campeche). However, this material was not found to confirm this information. Due to historical misidentifications, we are not considering this specimen, given the fact that Sutherland (2001: 36) indicates S. phaneroneurus as endemic to Honduras.

Breedlove (1986) also records the occurrence of this species in Mexico, citing four specimens, including Breedlove \& Almeda 48091 (MO! = $S$. capitatus Lundell), which not resembles $P$. phaneroneurum, as well as other materials deposited in the herbarium MO identified as $S$. phaneroneurus (Valdivia et al. 576!, 1272!; Vázquez et al. 509!, 581!), which correspond to S. orbicularis (Kunth) Blume sensu Burger \& Kuijt (1983).

\section{Acknowledgments}

We thank the virtual herbaria and libraries that provide herbaria specimens and books, without it this work would not have been realized. This is publication 15 in the Parasitic Plants Research Group technical series.

\section{References}

Breedlove, D.S. 1986. Listados Floristicos de Mexico - IV Flora de Chiapas. Mexico: UNAM. Available in <www. ibiologia.unam.mx/BIBLIO68/fulltext/lfl4.html>. Access on 10 July 2014.

Burger, W.C. \& Kuijt, J. 1983. Loranthaceae. In: Burger, W.C. (ed.). Flora Costaricensis. Fieldiana, Botany 13: 29-79.

Caires, C.S.; Gomes-Bezerra, K.M. \& Proença, C.E.B. 2014. A new combination in Peristethium (Loranthaceae) expands the genus' range into the Amazon-Cerrado ecotone. Acta Amazonica 44: 169-173.

Kuijt, J. 2012. Reinstatement and expansion of the genus Peristethium (Loranthaceae). Annals of the Missouri Botanical Garden 98: 542-577.

Lundell, C.L. 1942. Flora of Eastern Tabasco and adjacent Mexican areas. Contributions from the University of Michigan Herbarium 8: 1-74.

Sutherland, C.H.N. 2001. Plantas descritas originalmente de Honduras y sus nomenclaturas equivalentes actuales. Ceiba 42: 1-71.

Thiers, B. [continuously updated]. Index herbariorum: a global directory of public herbaria and associated staff. New York Botanical Garden's Virtual Herbarium. Available in <http://sweetgum.nybg.org/ih/>. Access on 10 July 2014. 
